\title{
СЕМАНТИЧЕСКИЙ АНАЛИЗ ЛЕКСЕМЫ ГОСУДАРСТВО ПО ДАННЫМ СЛОВАРНЫХ ДЕФИНИЦИЙ
}

\section{SEMANTIC ANALYSIS OF THE STATE LEXEME ACCORDING TO DICTIONARY DEFINITIONS}

\section{T. Erofeeva \\ Yu. Zhdanova}

Summary: The paper presents the lexicographical description of the definitions of the State lexeme which constitutes the core of the political lexical sphere. The material of the research was the data of dictionary references from ten dictionaries: six explanatory, three encyclopedic, and one political. Using the component analysis method, the semantic components comprising the semantic field of the studied lexeme are distinguished in ten dictionary definitions. It allowed to determine the structure of the lexeme under study which has the core including important mandatory semantic components of the word that are naming the definition; the pre-core area describing the forms of the territorial structure of a state; the periphery showing the characteristics of a state that represent encyclopedic meanings - that is, specific, important for one state in contrast to another, - and that are largely variable.

Keywords: political linguistics, vocabulary, lexicon, dictionary definition, component analysis method, semantic components, semantic field.
Политическая сфера коммуникации обусловлена выделением особой языковой подсистемы, которая находится на пересечении двух наук: лингвистики и политологии. Это соединение в настоящее время принято называть политической лингвистикой или лингвополитологией. Ее основная цель - исследование многообразных отношений между языком, мышлением, коммуникацией, субъектами политической деятельности и политическим состоянием общества [18, с. 7]. Такова формулировка, представленная А.П. Чудиновым в учебном пособии «Политическая лингвистика». Здесь охарактеризованы основные ее положения как научной дисциплины, её понятийный аппарат, свойства и функции политической коммуникации. Четвёртая глава пособия посвящена лексической характеристике политической коммуникации. В пособии подробно рассмотрена политическая метафора как сильное и эффективное средство воздействие на сознание общества. Тема власти интересует и социолингвистику. Так, в учебном пособии Н.Б. Вахтина и Е.В. Головко «Социолингвистика и социология языка» седьмая глава посвящена раскрытию проблемы языка и власти, где показано, «как использование различных лингвистических практик соотносится с распределением властных полномочий» [4, с. 297].
Ерофеева Тамара Ивановна

Д.филол.н., профессор, Пермский государственный национальный исследовательский университет genling.psu@gmail.com

жданова Юлия Владимировна

аспирант, Пермский государственный национальный исследовательский университет yukayokyok@gmail.com

Аннотация: В работе представлено лексикографическое описание дефиниции лексемы Государство, составляющей ядро политической лексической сферы. Материалом исследования послужили данные словарной дефиниции в десяти словарях: шести толковых, трех-энциклопедических, одного политического. Методом компонентного анализа в десяти словарных дефинициях выделены семантические компоненты, составляющие семантическое поле исследуемой лексемы. Это позволило определить структуру этой лексемы, имеющей ядро, куда вошли важные, обязательные семантические компоненты слова, называющие дефиницию; предъядерную зону, описывающую формы территориального устройства государства; периферию, где показаны те характеристики государства, которые представляют энциклопедические значения, то есть специфические, важные для одного государства в отличие от другого и во многом варьируемые.

Ключевые слова: политическая лингвистика, лексика, словарная дефиниция, метод компонентного анализа, семантические компоненты, семантическое поле.

Как видим, основу политического языка составляет политическая лексика, которая в лингвистических исследованиях рассматривается как система тематических классов слов, или тематических групп, выделяемых на основе социально-оценочного компонента [10], и во многом определяется соответствующей социально-политической ситуацией. Ядром политической системы является лексема Государство. Задача этой статьи - провести семантический анализ лексемы, используя данные словарных дефиниций в лексикографических источниках. К работе были привлечены следующие словари: лингвистические толковые словари - 6; энциклопедические словари - 3; политические словари - 1.

На этапе структурирования данных использован контент-анализ, компонентный анализ и количественный метод, которые позволили наглядно представить семантические компоненты семантики словарных дефиниций лексемы Государство в 10 словарях. Описание материала исследования проведено по схеме: название словаря; дефиниция лексемы Государство; семантические компоненты, выделяемые в семантике слова.

I. В. Даль. Толковый словарь живого великорусского 
языка (в табл. - Даль).

Государство. Ср. Царство, империя, королевство, земля, страна под управлением государя. // Cтар. Государствование, власть, сан и управление государя [5, с. 387].

Семантические компоненты: 1. Царство. 2. Империя. 3. Королевство. 4. Земля под управлением государя. 5. Страна под управлением государя. 6. Власть государя.

II. Словарь русского языка в четырёх томах под ред. А.П. Евгеньевой (в табл. - МАС).

Государство. Политическая организация общества во главе с правительством и его органами, с помощью которой государствующий класс осуществляет свою власть, обеспечивает охрану существующего порядка и подавление противников, а также страна с такой политической организацией [14, с. 339].

Семантические компоненты: 1. Политическая организация. 2. Органы управления. 3. Власть господствующего класса. 4. Охраняет порядок. 5. Подавляет классовые противоречия. 6. Страна с политической организацией.

III. Лопатин В.В., Лопатина Л.Е. Малый толковый словарь русского языка (в табл. - Лопат.).

Государство. Политическая форма организации общества во главе с правительством и другими органами, осуществляющими власть (исполнительными, законодательными, судебными), обеспечивающими охрану существующего порядка; территория, на которой существует такая политическая форма. Демократическое г., Монархическое г. [9, с. 98]. Семантические компоненты: 1. Политическая организация. 2. Имеет органы, осуществляющие власть. 3. Обеспечивает охрану, порядок. 4. Территория с политической организацией. 5. Формы государства (демократическая, монархическая).

IV. Ожегов С.И., Шведова Н.Ю. Толковый словарь русского языка (в табл. - Ож.-Шв.).

Государство. 1. Основная политическая организация общества, осуществляющая его управление, охрану его экономической и социальной структуры. 2. Страна, находящаяся под управлением политической организации, осуществляющей охрану её экономической и социальной структуры.

Государство в государстве. 1) Маленькое самостоятельное государство внутри большого; 2) организация, существующая внутри большой [11, с. 137].

Семантические компоненты: 1. Политическая организация. 2. Управляет обществом. 3. Охраняет эконо- мическую и политическую структуру. 4. Страна с политической организацией. 5. Маленькое государство внутри большого. 6. Организация, существующая внутри большой.

V. Современный толковый словарь русского языка / гл. ред. С.А. Кузнецов (в табл. - Кузнец.).

Государство 1. Политическая форма организации общества, осуществляющая управление обществом, охрану его экономической и социальной структуры. 2. Страна с определённой формой политической организации. // О системе органов управления, правительства. Государство в государстве. Об организации, существующей внутри другой как самостоятельная структура $[16$, с. 138$]$.

Семантические компоненты: 1. Политическая организация. 2. Управляет обществом. 3. Охраняет экономическую и политическую структуру. 4. Страна с политической организацией. 5. Система органов управления. 6. Организация, существующая внутри другой.

VI. Толковый словарь русского языка начала 21-го века: актуальная лексика / под ред. Г.Н. Скляревской (в табл. - Скляр.).

Государство. Политическая форма организации общества, осуществляющая управление обществом, охрана его экономической и социальной структуры; страна с определённой политической системой. Мафиозное государство. Правовое государство [17, с. 261].

Семантические компоненты: 1. Политическая форма организации. 2. Управляет государством. 3. Охраняет экономические и социальные структуры. 4. Страна с определенной политической системой.

VII. Советский энциклопедический словарь / гл. ред. А. М. Прохоров (в табл. - Сов. энц.).

Государство. Основное орудие политической власти в классовом обществе. Возникло в результате общественного разделения труда, появления частной собственности и образования антагонистических классов $[15$, c. 334].

Семантические компоненты: 1. Орудие власти. 2. Условия возникновения. 3. Власть классовом обществе.

VIII. Большой энциклопедический словарь / глав. ред. А.М. Прохоров (в табл. - Прохор.).

Государство. Политическая организация общества с определённой формой правления (монархия, республика). По форме государственного устройства государства 
может быть унитарным или федерацией [3, с. 301].

Семантической компоненты: 1. Политическая организация. 2. Монархия. 3. Республика. 4. Государственное устройство.

IX. Большая российская энциклопедия в 30 томах / отв. ред. С.Л. Кравец (в табл. - Кравец).

Государство. Основной институт политической системы общества, способ социального бытия в условиях политического отчуждения власти. В современной научной литературе г. обычно определяется как политико-территориальная суверенная организация политической власти, имеющая специальный аппарат управления и принуждения, способная делать свои веления обязательными для населения всей страны [2, с. 767].

Семантические компоненты: 1. Институт политической системы. 2. Способ социального бытия. 3. Политико-суверенная организация. 4. Имеет аппарат управления. 5. Обязательно для всего населения.

Х. Краткий политический словарь / ред. Л.А. Оников, Н.В. Шишилин (в табл. - Полит.).

Государство. Важнейший социально-политический институт общества, основа его политической системы, осуществляющий политическую власть в процессе регулирования поведения людей, их групп и объединений, взаимоотношений между ними и проведения своей внутренней и внешней политики. Основными признаками г. являются наличие 1) особого механизма осуществления политической власти (функций г.) в виде обособленной системы органов, организаций и учреждений; 2) системы санкционированных политической властью норм и установлений, т.е. права; 3) ограниченной территории, определяющей пространственные рамки распространения соответствующей власти.

Формы правления... формы территориального устройства, ... формы политического режима... [8].

Семантические компоненты: 1. Социально-политический институт. 2. Политическая система норм, правил. 3. Механизм власти. 4. Осуществление внутренней и внешней политики. 5. Форма территориального устройства. 6. Форма политического режима.

Полученные семантические компоненты в некоторых случаях объединялись с помощью контент-анализа в более крупные языковые единицы, определяющие языковые смыслы лексемы Государство. Назовем их дескрипторами вслед за И.М. Кобызевой [7, с. 188]. Определилось 12 дескрипторов, отмеченных в используемых для анализа 10 словарных дефинициях лексемы Государство. В таблице они помещены в первом вертикальном столбце. Горизонтально в таблице названы словари, привлеченные к работе; последний столбец указывает частоту того или иного семантического компонента-дескриптора (см. табл. 1).

Для выявления структуры семантики лексемы Государство построим семантическое поле, состоящее

Таблица 1.

Семантические компоненты лексемы Государство Semantic components of the lexeme State

\begin{tabular}{|l|c|c|c|c|c|c|c|c|c|c|c|}
\multicolumn{1}{|c|}{ Дескрипторы } & Даль & МАС & Лопат. & Ож.-Шв. & Кузнец. & Скляр. & Сов. энц. & Прохор. & Кравец & Полит. & Частота \\
\hline Земля (территория) под управл-ем & + & + & & & & & & & & + & 3 \\
\hline Страна под управл-ем & + & + & & + & + & + & & & & & 5 \\
\hline Власть государя, господ, класса & + & + & & & & & + & & & & 3 \\
\hline Полит. орган, система, устр-во & & + & + & + & + & + & & + & + & + & 8 \\
\hline Органы управл-я & & + & + & + & + & + & & & + & + & 7 \\
\hline $\begin{array}{l}\text { Охрана порядка } \\
\text { (подавляет классовые противореч.) }\end{array}$ & & + & + & + & + & + & & & + & + & 7 \\
\hline $\begin{array}{l}\text { Формы гос-ва } \\
\text { демократия, монархия) }\end{array}$ & + & & + & & & & & + & & & 4 \\
\hline $\begin{array}{l}\text { Маленькое гос-во (организация) } \\
\text { внутри большого }\end{array}$ & & & & + & + & & & & & & 2 \\
\hline Орудие власти & & & & & & & + & & & & 2 \\
\hline Условия возникновения гос-ва & & & & & & & + & & & & 1 \\
\hline Способ соц. бытия & & & & & & & & & + & & 1 \\
\hline Формы полит. режима & & & & & & + & & & & + & 2 \\
\hline
\end{tabular}




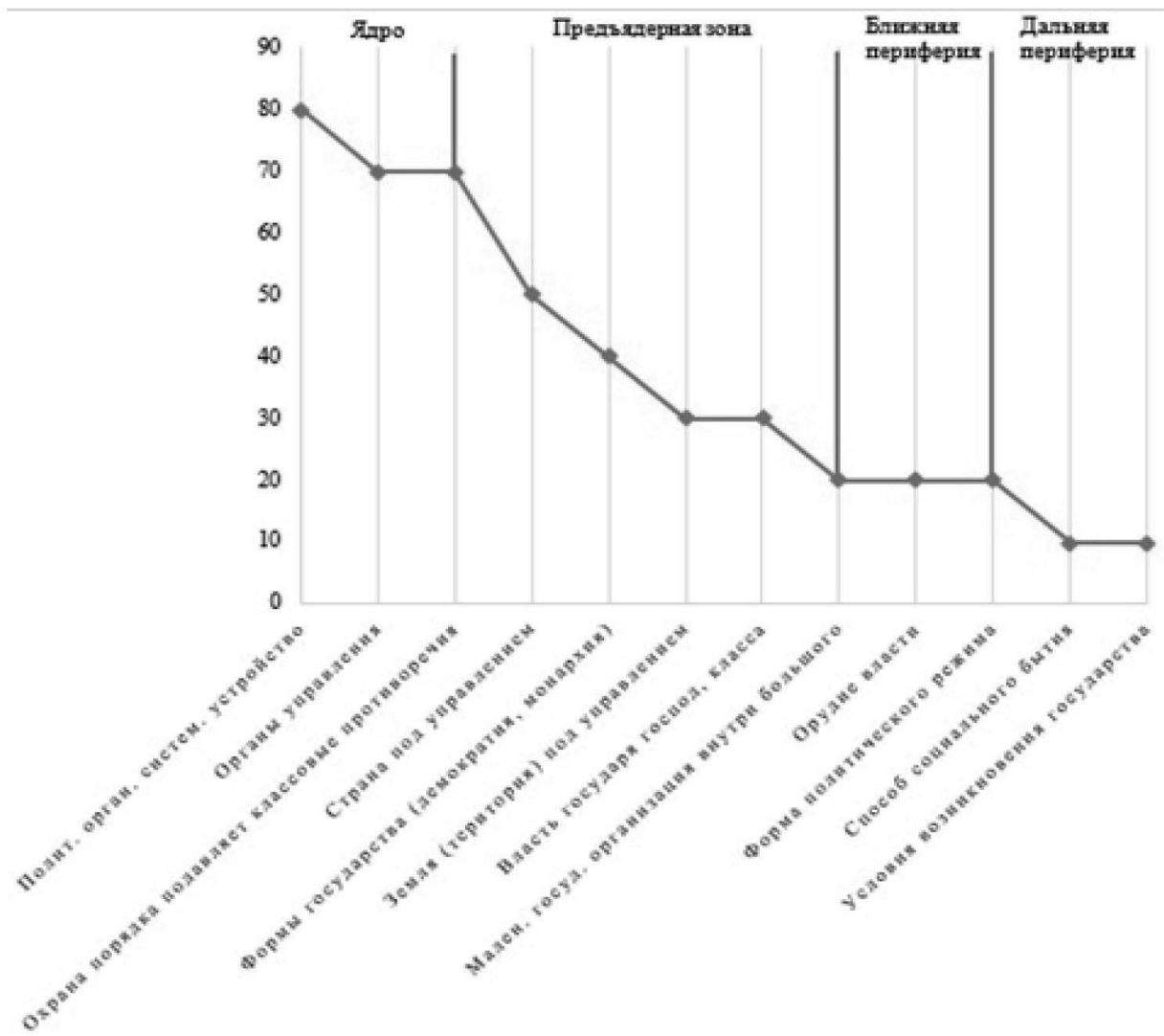

Рис. 1. Семантическое поле лексемы Государство

из ядра, предъядерной зоны и периферии (см. работы В.Г. Адмони 1964; И.А. Стернина 1979, 2007; Ерофеевой, Миненко 2020), представленного на рисунке 1.

Как и ожидалось, ядром исследуемой лексемы выступает семантический компонент, называющий дефиницию Политическая организация и её синонимические варианты Институт политической системы, Социально-политический институт - всего 8 реакций. В ядерной зоне присутствуют реакции, определяющие главные функции государства - Органы управления - 7 реакций; Охрана порядка (подавляет классовые противоречия) 7 реакций.

Предъядерная зона описывает формы территориального устройства государства - Страна под управлением (5 реакций), Земля (территория) под управлением (3 реакции); Формы правления: демократическое, монархическое (4 реакции); Власть государя, господствующего класса (3 реакции).
Периферия состоит из ближней и дальней периферий. К ближней периферии относятся 3 дескриптора: Маленькое государство, организация внутри большого (2 реакции); Орудие власти (2 реакции); Форма политического режима: мафиозное, правовое (2 реакции). Эти специфические особенности государства, отмеченные в периферии, важны для характеристики одного государства в отличие от другого. Дальняя периферия представлена двумя дескрипторами - Способ социального бытия как обязательность исполнения для населения и Условия возникновения государства. Дескрипторы имеют энциклопедический характер и необязательны для определения данной лексемы. Итак, проведенный анализ дефиниции лексемы Государство показал сложный характер ее семантической структуры, выделив в ней существенные, обязательные семантические компоненты, менее важные, но дополняющие семантическую структуру, а также те элементы, которые представляют энциклопедические знания и могут не отмечаться в словарях толкового типа.

\section{ЛИТЕРАТУРА}

1. Адмони В.Т. Качественный и количественный анализ грамматических явлений // Теоретические проблемы современного совецкого языкознания. М.: Наука, 1964. С. 56-68.

2. Большая российская энциклопедия: в 30 т. / отв. ред. С.Л. Кравец. М.: Большая российская энциклопедия. Т. 7. М.: Большая российская энциклопедия, 


\subsection{7 c.}

3. Большой энциклопедический словарь / гл. ред. А.М. Прохоров. 2-е изд. М.: Большая российская энциклопедия; СПб.: Норинт, 1997. 1434 с.

4. Вахтин Н.Б., Головко Е.В. Социолингвистика и социология языка: Учебное пособие. СПб.: И.Ц. «Гуманитарная академия»; Изд-во Европейского университета в Санкт-Петербурге, 2004. 336 с.

5. Даль В.И. Толковый словарь живого великорусского языка: в 4 т. М.: Русский язык, 1978. Т. 1. 699 с.

6. Ерофеева Т.И., Миненко Е.В. Лексика выборы / еlection в наивном представлении русских и англичан // Современная наука: актуальные проблемы теории и практики. Серия: Гуманитарные науки. 2020. № 11. С. 156-160.

7. Кобызева И.М. Лингвистическая семантика: Учебник. М.: Эдиториал УРСС, 2000. 352 с.

8. Краткий политический словарь / ред. Л.А. Оников, Н.В. Шишилин. 6-е изд., доп. М.: Политиздат, 1989. 623 с.

9. Лопатин В.В., Лопатина Л.Е. Малый толковый словарь русского языка. 2-е изд., стер. М.: Русский язык, 1993.704 с.

10. Миненко Е.В. Фрагмент политической картины мира в наивном представлении русских и англичан (экспер. исследования). Автореферат ... канд. филолог. наук. Пермь, 2017. $18 \mathrm{c}$.

11. Ожегов С. И., Шведова Н. Ю. Толковый словарь русского языка. 2-е изд. М.: Азъ, 1995. 928 с.

12. Стернин И.А. Контрастивная лингвистика. Проблемы теории и методики исследования. М.: АСТ; Восток-Запад, 2007. 282 с.

13. Стернин И.А. Проблемы анализа структуры значения слова. Воронеж: Изд-во Воронеж, ун-та, 1979. 156 с.

14. Словарь русского языка: в 4 т. / под ред. А.П. Евгеньевой. Т.1. М.: Русский язык, 1985. 696 с.

15. Советский энциклопедический словарь / гл. ред. А.М. Прохоров. М.: Советская энциклопедия, 1980. 1600 с.

16. Современный толковый словарь русского языка / гл. ред. С.А. Кузнецов. М.: Ридерз Дайджест, 2004. 959 с.

17. Толковый словарь русского языка начала 21-го века: актуальная лексика / под ред. Г.Н. Скляревской. М.: Эксмо, 2006. 1136 с.

18. Чудинов А.П. Политическая лингвистика: учебное пособие / 3-е изд. испр. М.: Флинта; Наука, 2008. 256 с.

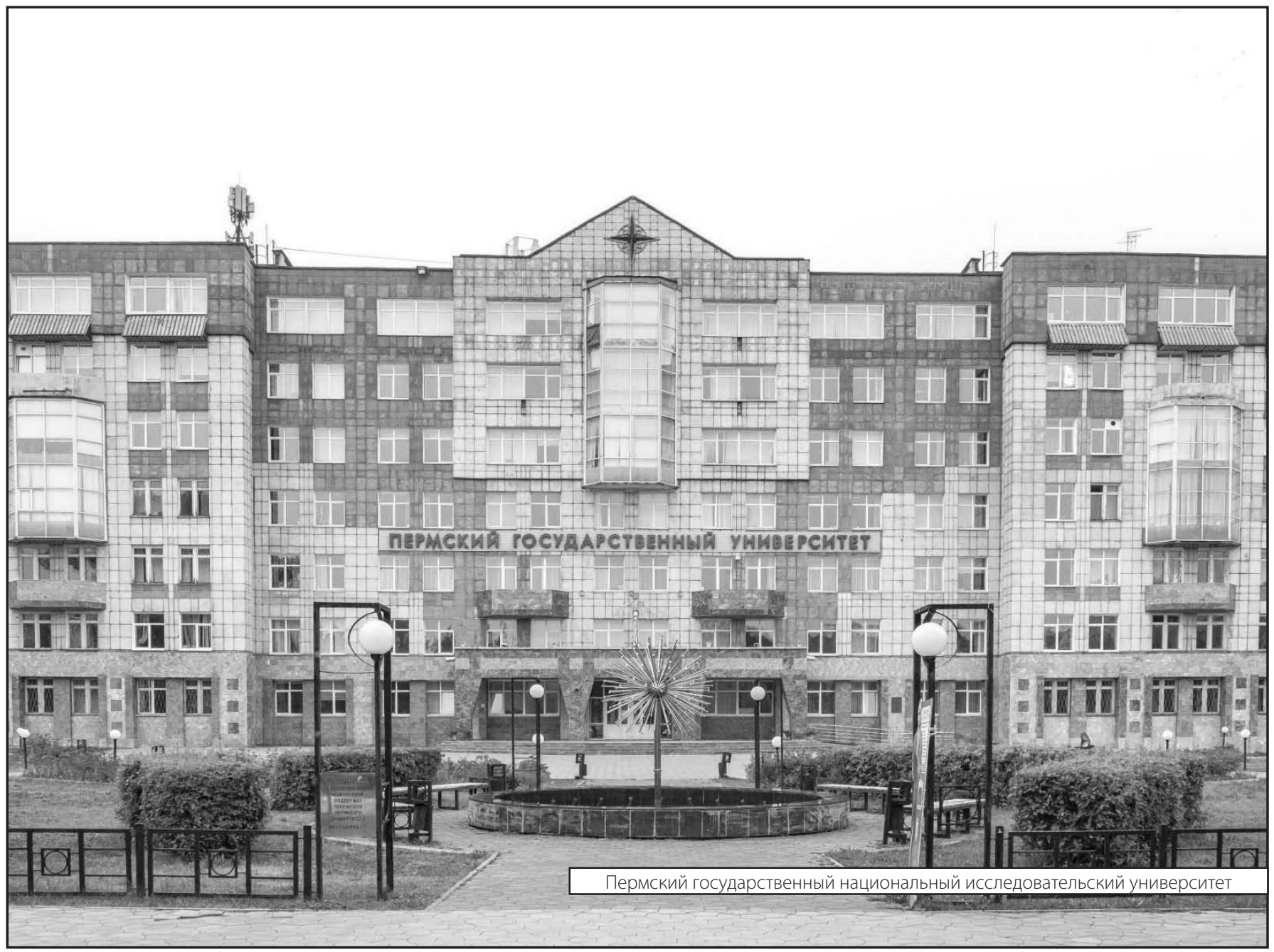

